\title{
Detection of Plasmodium in Anopheles arabiensis using nested-PCR in Jazan region, Saudi Arabia
}

\author{
O.M. Dafalla', A.A. Alsheikh ${ }^{1}$, Abakar AD², WS Mohammed', Samira H Abd Elrahman ${ }^{3}$ \\ and EM Noureldin ${ }^{1 *}$ \\ ${ }^{1}$ National Center for Vector-Borne Diseases, MoH-Jazan, Saudi Arabia \\ ${ }^{2}$ Department of Medical Parasitology, Faculty of Medical Laboratory Sciences, University of Gezira, Sudan \\ ${ }^{3}$ Blue Nile National Institute for Communicable Diseases, Wad Medani, Sudan
}

\begin{abstract}
The present study was carried out in 26 villages at two Governates (Al-Khobah, and Haroob) in Jazan Region in Southwest Saudi Arabia to identify and detect the presence of Plasmodium in Anopheles arabiensis using nested-PCR technique. An. Arabiensis was identified by PCR and it was the predominant Anopheles mosquito in all the collection sites. A total of 257 An. Arabiensis females were collected and two samples from two villages (Almuatan and Alsabkha) out of 107 (1.87\%) female mosquitoes from Haroob Governate were found positive for the sporozoites of Plasmodium falciparum. Similarly, 3 out of 150 (2\%) female mosquito samples from Um-alkhameir, AL-Khobah Governate, were also found positive. Around fourfold increase of thesporozoite rate (from 0.61 to $2.0 \%$ ) in An. arabiens is in AL-Khobah Governate has been observed compared to the previous study of 2007-2008. The wide spread of An. arabiensis in Jazan region with $>90 \%$ of the malaria cases caused by $P$. falciparum, along with infectivity rate ranges between 1.87 to 2.0\% for $P$. falciparum in Al-Khobah and Haroob Governates, suggests that P. falciparum is the most predominant malaria parasite and An. Arabiensis is a very efficient malaria vector in the region. It also suggestsmore in-depth researches on the ecology, behavior, and control of An. Arabiensis to promote area-specific control programs.
\end{abstract}

KEY WORDS: MALARIA, JAZAN, SAUDI ARABIA, PLASMODIUM FALCIPARUM, PCR, ANOPHELESARABIENSIS

\section{ARTICLE INFORMATION:}

*Corresponding Author: omerosa@yahoo.com

Received $14^{\text {th }}$ May, 2017

Accepted after revision $27^{\text {th }}$ June, 2017

BBRC Print ISSN: 0974-6455

Online ISSN: 2321-4007 CODEN: USA BBRCBA

$\therefore$ Thomson Reuters ISI ESC and Crossref Indexed Journal

NAAS Journal Score 2017: 4.31 Cosmos IF : 4.006

- A Society of Science and Nature Publication, 2017. All rights reserved.

Online Contents Available at: http//www.bbrc.in/ 


\section{INTRODUCTION}

Malaria is an infectious disease caused by the bites of female Anopheles mosquitoes infected with Plasmodium spp. (Cowman \& $\mathrm{C}$ Crabb, 2006).There are approximately fifteen Anopheles species present in Saudi Arabia, but only four play a major role in parasitic transmission; these species are Anopheles arabiensis, Anopheles sergentii, Anopheles stephensi, and Anopheles Superpictus (Sebai, 1988; Zahar, 1985). Anopheles arabiensis has been identified as the primary vector transmitting malaria in Tihama area (southwest of Saudi Arabia and northeast Yemen)(Alsheikh, 2004),andconsidered to be a very efficient transmitting vector in the Afro-tropical area, with large variations in life behaviour including feeding, resting, and breeding(Beiernand Koros, 1991; Coetzee and Le Sueur, 1988).Five species of Plasmodium have long been recognized to infecthumans; these species include Plasmodium falciparum (the most virulent form of malaria with approximately 90\% malaria deaths globally), Plasmodium vivax (the most common cause of malaria globally), Plasmodiummalariae, Plasmodiumovale and Plasmodiumknowlesi (WHO,2016).

The annual estimates of WHO in December 2015 for malaria were 214 million cases of and 438000 deaths, with 3.2 billion people were at risk of malaria transmission (WHO, 2016). The disease remains a considerable threat due to several reasons, such as transmission enabling environments, poverty, lack of awareness, impaired health system infrastructures, political and socioeconomic problems, mass population migration and the emergence of multi-drug resistance (WHO, 2011; WHO, 2014).

In Saudi Arabia, about 5\% of the Saudi population is at risk of malaria (approximately 2.4 million people) (Alsheikh, 2011). The disease is restricted to the South Western region of Tihama (Jazan and Asir), where more than 70\% of all malaria cases in the country are occurred (El Hassan et al, 2015). Moreover, from 2000 to 2014 there were 5522 known locally acquired cases of malaria and around 9936 imported cases (El Hassan et al, 2015).

Identifying the presence of sporozoites of human malaria in the salivary glands of potential Anopheline vectors is the final step in establishing vector status(Alsheikh, 2004).Moreover, the determination of sporozoite rates has been considered as the most important entomological factor in the epidemiology of human malaria (Wirtz et al, 1987).

The intensity of malaria transmission is determined by calculating the entomological inoculation rate (EIR), as a simple estimated parameter, which is the product of the man-biting rate (defined as the number of bites per person per night) and the sporozoite rate (Reisen and Boreham, 1982; Dye, 1986). Although vectorial capacity is also a useful estimator of potential transmission intensity (Garret- Jones and Shidrawi, 1969), it is often difficult to determine with reliability owing to the numerous biological parameters required for its estimation.There are three techniques have been used for identification of Plasmodium sporozoites in salivary glands of Anopheles female mosquitoes. These include; ordinary microscopy dissection, immunological techniques, and polymerase chain reaction (PCR) (Burkot et al, 1984; Beier et al, 1988; Alsheikh, 2004).The latter has the potential for detecting and screening malaria parasites, especially in endemic regions, as well as in monitoring the effectiveness of malaria therapy (Moody, 2002; Morassin et al, 2002; Gama et al, 2007).Al-Maktari and Bassiouny (1999)in Yemen have recorded sporozoitesrate of $0.7 \%$ (4/600) for P. falciparum in An. arabiensis using microscopy method.

In Jazan region, Saudi Arabia, Al-Sheikh (2011) reported $0.61 \%$ as sporozoite rate of $P$. falciparum in $A$. arabiensis collected in 2007 - 2008 using nested PCR. To the best of our knowledge, since that date no other data in Jazan region or other areas of Saudi Arabia has been published on the determination of sporozoite rate of $P$. falciparum in A. arabiensis using nested-PCR. The present study thushas been conducted to detect and identify the infectious Plasmodium species inside the malarial vector Anopheles arabiensis using nested-PCR techniques comparing previous data.

\section{MATERIAL AND METHODS}

This study was carried out at two small Governates (AlKhobah, and Haroob) in the Jazan Region in Southwest Saudi Arabia, lies between $16^{\circ}-12$, and $18^{\circ}-25$, latitude north (Alsheikh, 2011), with a total area of about 22,000 $\mathrm{km} 2$ and 1.3 million populations (census 2011). Thirty percent of the population concentrated in six major cities, and the remainders living in over 3500 villages (Fig. 1) (Alsheikh, 2011).

Jazan region is situated in the subtropical zone and has average monthly temperatures ranging between $25.8^{\circ} \mathrm{C}$ in January to $33.4^{\circ} \mathrm{C}$ in July. The average relative humidity ranges from 55\% and 72.5\%. The rainy season is started at August through October with a monthly average of 77 and $56.7 \mathrm{~mm}$, respectively (Alsheikh, 2011).

Anopheles arabiensis specimens were collected from indoor human dwellings of 26 villages distributed in tow Governates (Al-Khobah and Haroob) from January to December 2015 (Table 1). The two Governates were selected based on the presence of An. Arabiensis and the reports of malaria cases.The collection of specimens was performed using Pyrethrum Knockdown (PKD) 


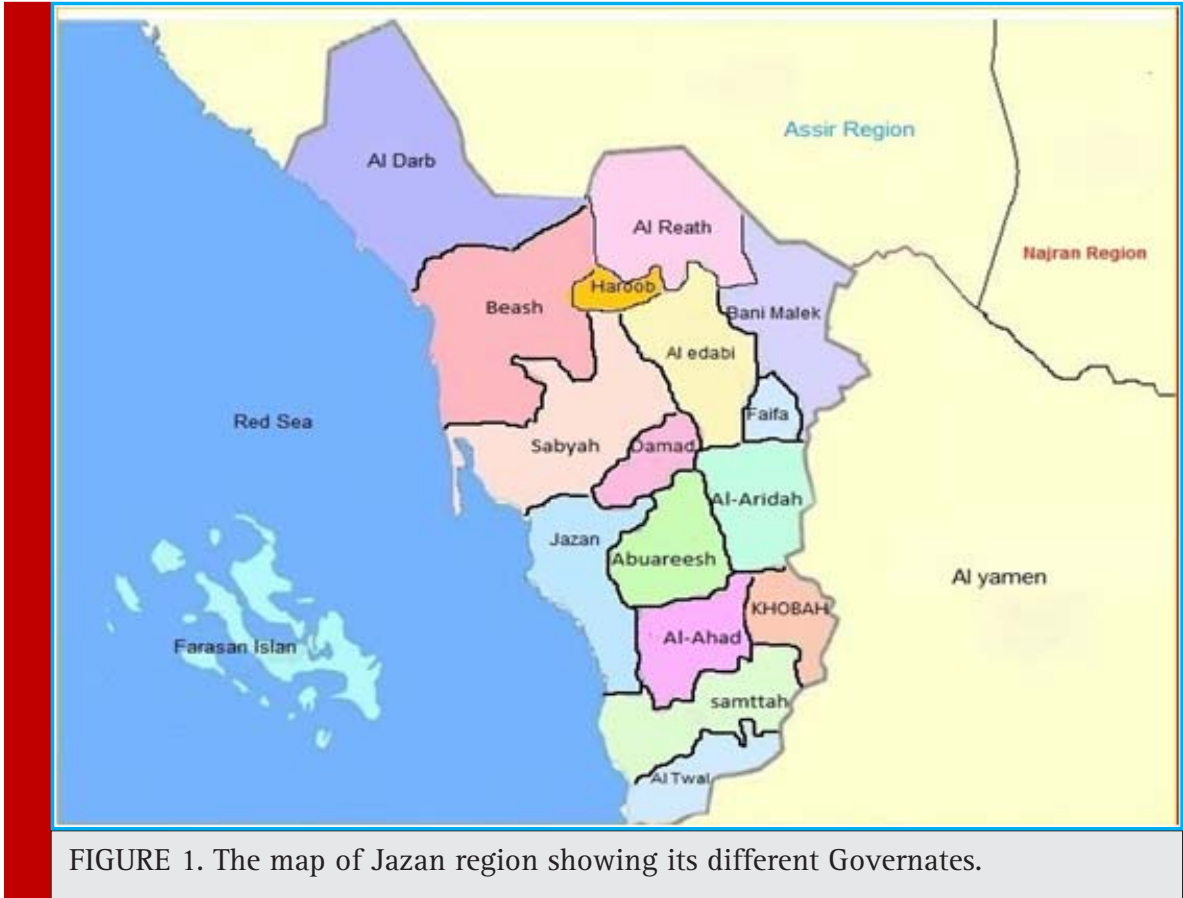

collections as described by WHO (1992). Collected mosquitoes were brought to the National Center for VectorBorne Diseases in Jazan for morphological and molecular identification, and sporozoite rate determination.
The collected mosquitoes were identified based on morphological features given by Glick (1992) and Mattingly (1956). A total of 257 An. Arabiensis females were preserved individually in $1.5 \mathrm{ml}$ plastic tube, labeled,

\begin{tabular}{|c|c|c|c|c|c|}
\hline \multirow{2}{*}{$\begin{array}{l}\text { Serial } \\
\text { No. }\end{array}$} & \multicolumn{2}{|c|}{ Al-khobah Governate } & \multirow{2}{*}{$\begin{array}{l}\text { Serial } \\
\text { No. }\end{array}$} & \multicolumn{2}{|c|}{ Haroob Governate } \\
\hline & Villages & No. of samples & & Villages & No. of samples \\
\hline 1 & Wabrah & 5 & 1 & GaeimMahroog & 13 \\
\hline 2 & GaeimMzubaid & 15 & 2 & Haroob city & 4 \\
\hline 3 & ZahrAljamal & 5 & 3 & Al-muatan & 12 \\
\hline 4 & Um-alturab & 17 & 4 & Al-gahmah & 9 \\
\hline 5 & Al-mujarad & 19 & 5 & Al-sabkhah & 21 \\
\hline 6 & Al-mushbah & 6 & 6 & Al-maseer & 9 \\
\hline 7 & Al-mudeirah & 6 & 7 & Al-zamlah & 11 \\
\hline 8 & Al-mafrag & 5 & 8 & Al-dahmah & 11 \\
\hline 9 & Al-abteiah & 11 & 9 & Al-zahab & 9 \\
\hline 10 & Um-alkhameir & 22 & 10 & Al-kudmy & 8 \\
\hline 11 & Al-garn & 5 & & & \\
\hline 12 & Al-girwaneiah & 6 & & & \\
\hline 13 & Um-alhegil & 7 & & & \\
\hline 14 & Al-rahmaneiah & 7 & & & \\
\hline 15 & Al-jarshab & 8 & & & \\
\hline 16 & Shargan & 6 & & & \\
\hline Total & & 150 & & Total & 107 \\
\hline
\end{tabular}




\begin{tabular}{|c|c|c|c|c|}
\hline Species & Primer Name & Sequence (5-3) & $\begin{array}{l}\text { PCR Product } \\
\text { Size (BP) }\end{array}$ & PCR Condition \\
\hline Plasmodium sp. & $\begin{array}{l}\text { rPLU5 } \\
\text { rPLU6 }\end{array}$ & $\begin{array}{l}\text { CCTGTTGTTGCCTTAAACTTC } \\
\text { TTAAAATTGTTGCAGTTAAAACG }\end{array}$ & 1100 & $\begin{array}{l}\text { Initial denaturation at } 94^{\circ} \mathrm{C} \text { for } 3 \\
\text { min, } 35 \text { cycles of denaturation at } \\
94^{\circ} \mathrm{C} \text { for } 60 \text { seconds, annealing } \\
\text { at } 60^{\circ} \mathrm{C} \text { for } 90 \text { seconds, } \\
\text { extension at } 72^{\circ} \mathrm{C} \text { for } 90 \text { seconds } \\
\text { and final extension for } 5 \text { minutes }\end{array}$ \\
\hline P. falciparum & $\begin{array}{l}\text { rFAL1 } \\
\text { rFAL2 }\end{array}$ & $\begin{array}{l}\text { TTAAACTGGTTTGGGAAAACC } \\
\text { AAATATATT } \\
\text { ACACAATGAACTCAATCATGA } \\
\text { CTACCCGTC }\end{array}$ & 205 & $\begin{array}{l}\text { Initial denaturation at } 94^{\circ} \mathrm{C} \text { for } 3 \\
\text { min, } 35 \text { cycles of denaturation at } \\
94^{\circ} \mathrm{C} \text { for } 60 \text { seconds, annealing } \\
\text { at } 55^{\circ} \mathrm{C} \text { for } 90 \text { seconds, } \\
\text { extension at } 72^{\circ} \mathrm{C} \text { for } 90 \text { seconds } \\
\text { and final extension for } 5 \text { minutes }\end{array}$ \\
\hline P. vivax & $\begin{array}{l}\text { rVIV1 } \\
\text { rVIV2 }\end{array}$ & $\begin{array}{l}\text { CGCTTCTAGCTTAATCCACAT } \\
\text { AACTGATAC } \\
\text { ACTTCCAAGCCGAAGCAAAGA } \\
\text { AAGTCCTTA }\end{array}$ & 120 & $\begin{array}{l}\text { Initial denaturation at } 94^{\circ} \mathrm{C} \text { for } 3 \\
\text { min, } 35 \text { cycles of denaturation at } \\
94^{\circ} \mathrm{C} \text { for } 60 \text { seconds, annealing } \\
\text { at } 55^{\circ} \mathrm{C} \text { for } 90 \text { seconds, } \\
\text { extension at } 72^{\circ} \mathrm{C} \text { for } 90 \text { seconds } \\
\text { and final extension for } 5 \text { minutes }\end{array}$ \\
\hline An. arabiensis & $\begin{array}{l}\text { Universal primer } \\
\text { Species specific }\end{array}$ & $\begin{array}{l}\text { GTG TGC CCC TTC CTC GAT GT } \\
\text { AAG TGT CCT TCT CCA TCC TA }\end{array}$ & 315 & $\begin{array}{l}\text { Initial denaturation at } 94^{\circ} \mathrm{C} \text { for } 3 \\
\text { min, } 35 \text { cycles of denaturation at } \\
94^{\circ} \mathrm{C} \text { for } 60 \text { seconds, annealing } \\
\text { at } 50^{\circ} \mathrm{C} \text { for } 60 \text { seconds, } \\
\text { extension at } 72^{\circ} \mathrm{C} \text { for } 60 \text { seconds } \\
\text { and final extension for } 5 \text { minutes }\end{array}$ \\
\hline
\end{tabular}

capped, and stored at -86 until further investigation. After removing the legs, wings, and abdomen, the mosquito samples were homogenized individually in a mortar and pestle (mini borosilicate glass chamber length $60 \mathrm{~mm} /$ pestle diameter $9.0 \mathrm{~mm}$ 3.0Ml, Fisherbrand) in $100 \mu \mathrm{L}$ of Minimum Essential Media (MEM) (manufactured Euro Clone, UK). The homogenate was saved in -86 degree till next procedure.

\section{4- DNA EXTRACTION}

DNA was extracted from the stored homogenate using RealLine DNA - Extraction 2 (BIORON Diagnostic, Germany) following the manufacture's recommendations: $300 \mu \mathrm{L}$ of lysis Reagent with sorbent (magnetic particles) added to homogenate in 1.5 tubes and placed into the thermo shaker for five minutes at $65^{\circ} \mathrm{C}, 1300 \mathrm{rpm}$. Then $400 \mu \mathrm{L}$ of DNA precipitation solution was added to each tube and mixed for 15 seconds in a vortex. Samples were then centrifuged at $13000 \mathrm{rpm}$ for five minutes at room temperature then the supernatant discarded and the pellet was washed twice and driedfor 2-3 minutes at room temperature. Specimen solution used to re-suspend the DNA. The extracted DNA stored at $-86^{\circ} \mathrm{C}$ till next procedure

The morphological identification of Anopheles arabiensis has been confirmed by PCR using the procedure described by Scott et al (1993), and the primer used and PCR conditions are shown in Table 2. Nested PCR procedures were carried out for detection and identification of Plasmodium species as described by Snounou et al. (1993a). DNA samples were amplified by oligonucleotide primers obtained from Integrated DNA Technology (Belgium), targeting the Plasmodium small subunit ribosomal RNA (ssRNA) genes (Waters and McCutchan, 1989) (Table 2). Primer pair's rPLU5 and rPLU6 used to detect Plasmodium genus in Primary amplification and species-specific primers rFAL1/rFAL2 (P. falciparum) and rVIV1/rVIV2 ( $P$. vivax) for nested PCR in 2 separated reactions.

In brief, primary and nested PCR were carried out in total $25 \mu \mathrm{l}$ reaction volume, each containing $12.5 \mu \mathrm{l}$ GoTag ${ }^{\circledR}$ G2 green master mix ready to use from Promega and $25 \mu \mathrm{M}$ of each primer. Five $\mu \mathrm{l}$ of extracted DNA was used as a sample for the primary amplification and 2 $\mu l$ of the PCR product for the nested PCR. In each run, negative and positive controls were included. Thermal cycling was done in T100 thermal cycler (Bio-Rad, USA). PCR primers and conditions are shown in Table 2. The PCR products of nested amplification were analyzed by gel electrophoresis (1.5 agarose in Tris-Acetate EDTA buffer) staining with ethidium promide. The visualization was carried out using Gel Doc XR Imaging System (Bio-Rad). 




\section{RESULTS}

A total of $315 \mathrm{bp}$ segments of the IGS region of rRNA gene sequences of $A n$. Arabiensis were amplified (Figure 2). An. arabiensis was found as the predominant Anopheles mosquitoes in all the collection sites. All samples which were previously identified morphologically as An. arabiensis had beenalso molecularly confirmedby PCR(Fig 2).

Our molecular surveillance covered a total of 26 villages distributed in tow Governates (16 in Al-Khobah and 10 in Horoob) and lasted from January to December 2015. Two samples from two villages (Almuatan and Alsabkha) out of one hundred and seven (1.87\%) female mosquitoes collected from HaroobGovernate were found positive for the sporozoites of Plasmodium falciparum (Table 3).

Similarly, three out of one hundred fifty (2\%) female mosquito samples collected from 16 villages of ALKhobahGovernate were also found positive. These three positive samples were from Um Alkhameir village. All the positive nested PCR samples that detect $P$. falciparum show band in (205bp) (Fig 3).

\section{DISCUSSION}

Anopheles arabiensis is the potential primary vector of malaria in Jazan region. Alsheikh (2004)has identified An. arabiensis in the Tihama region (Saudi Arabia and Yemen) using species-specific diagnostic PCR, and showed that it is the only member of An. gambiae complex found in the Tihamaregion.In this study, the only detected Plasmodium species inthe femaleof $A n$. Arabiensis mosquitoes using nested-PCR method isPlasmodium falciparum, aresult which coincides with the findings of Alsheikh (2004)who reported that $P$. falciparum represents more than 95\% of malaria cases in the Tihama area (including Jazan region).The determination of sporozoites infection in wild Anopheles mosquitoes

\begin{tabular}{|l|l|l|l|l|}
\hline \multicolumn{6}{|c|}{ Table 3. Detection of Plasmodium sporozoites from An. arabiensis by PCR method } \\
\hline Governate & $\begin{array}{l}\text { No of villages } \\
\text { surveyed }\end{array}$ & $\begin{array}{l}\text { Total samples } \\
\text { collected }\end{array}$ & Positive samples & Species detected \\
\hline Horoob & 10 & 107 & $2(1.87 \%)$ & P. falciparum \\
\hline AlKhobah & 16 & 150 & $3(2 \%)$ & P. falciparum \\
\hline Total & 26 & 257 & $5(2.3)$ & P. falciparum \\
\hline
\end{tabular}




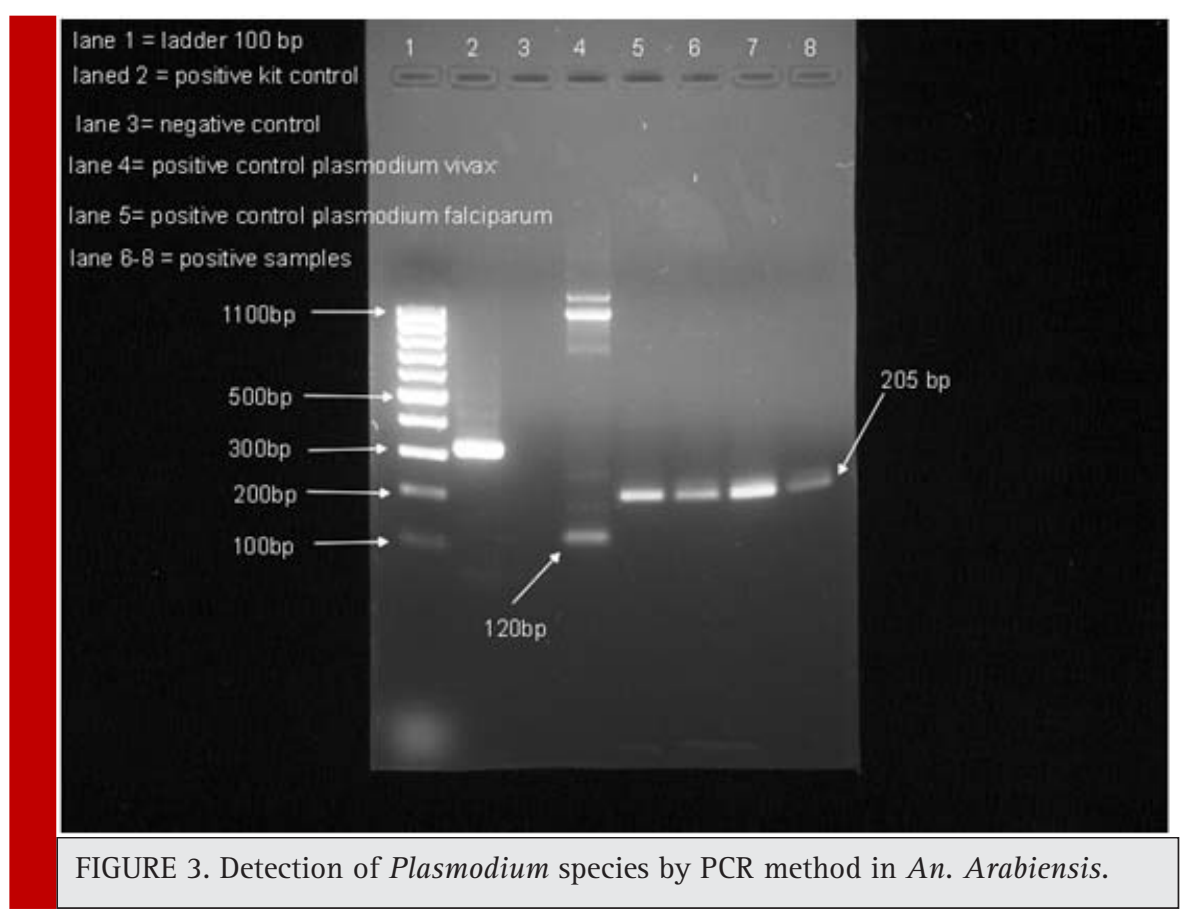

considers an integral part in vector incrimination and malaria transmission dynamics in affected areas and epidemiological research (Alsheikh, 2004).

In this study, Thesporozoite rate of $1.87 \%$ and $2 \%$ inHaroob and AlkhobahGovernates, respectively, (Table 3) reinforces the need to intensify the control efforts to compact the vector and reduce malaria transmission. We noticed a fourfold increase in thesporozoite rate of P. falciparum in An. arabiensis in Alkhobah Governate in the present study from 0.61 to $2 \%$ compared to the previous study in 2007-2008 (Alsheikh, 2011). This could be attributed to the current war on the border of Yemen, where Alkhobah is located, which hinders the control measures against An. arabiensis usually used to be conducted in the area before the start of the war.

Harada et al. (2000) have also observed fourfold increase in thesporozoite rate (0.62 to 2.2\%) in Anophelesgambiaes. s. in Ghana using the PCR method. In Solomon's Islands, $P$. falciparum was detected in 15.2\% of Anophelesfarauti by PCR technique (Wilson et al, 1998).Few previous studies in the Tihamaregion had determined the sporozoite rate of Plasmodium species in Anopheles mosquitoes. For instance inSaudi Arabia, Plasmodium sporozoites had been detected in $0.65 \%$ of An. arabiensis using nested- PCR(Alsheikh, 2004), and in $0.9 \%$ of 2921 An. arabiensis (23 P. falciparum, and $2 P$. vivax) using ELISA method, while $P$. falciparumsporozoites were detected in An. sergentii (2/295) and a single female of $A n$. algeriensisin Yemen (Al-Eryani et al., 2016).
In East African countries such as Sudan, the $P$. falciparum sporozoite rate in An. arabiensis was found to be $4.5 \%$ in Sennar State using ELISA technique(Elmahdi et al., 2012), and 1.4-15\% in eastern part of the country (Hamad et al., 2002). While in Ethiopia, it was 0.3\% for $P$. falciparum and 0.5\% for P. vivax (Tirados et al., 2006), and in Eritrea, it ranges from 0.54 to $1.3 \%$ (Shililu et al., 2004). In Asia, the sporozoite rate of $P$. falciparum was higher (10\%) in An. stephensi from District Shiekhupura in Pakistan (Oneeb et al., 2015). Whereas, in various parts of India, sporozoite rates range from 0.012 to $0.2 \%$ in Anophelesannularis were reported using microscopic method, but the malaria parasite species could not be identified (Dash et al., 1982; Gunasekaran et al., 1989; Ghosh et al., 1985).However, Mahapatra et al. (2006) in Keonjhar district, Orissa, India, have detected 3.4\% sporozoite rate in Anophelesannularis using PCR technique, and have identified the malaria parasite species to be $P$. falciparum.

Infectivity rate of $10.6 \%$ P. falciparum in Anopheles gambiae complex was found by Snounou et al.(1993b)in Guinea Bissau using PCR method. Four out of five (80\% sporozoite rate) wild caught Anophelesdirus were found positive for the sporozoites of $P$. falciparum using PCR method, although they were negative when using ELISA technique (Tassanakajon et al., 1993), which reflected the high sensitivity of the PCR method.Variations in sporozoite rates in $A n$. arabiensis from a country to another or within the same country could be attributed to the seasonal variations in transmission(Alsheikh, 2004).The wide spread of Anopheles arabiensis in Jazan 
region with $>90 \%$ of the malaria cases caused by $P$. falciparum, along with infectivity rate ranges between 1.87 to $2.0 \%$ for $P$. falciparum, suggests more in-depth researches on its ecology, behavior, and control to promote area-specific control programs.

\section{CONCLUSION}

The current study indicated the significance of using PCR technology in detecting the presence of Plasmodium species in Anopheles mosquitoes. Our findings revealed an infectivity rate of Anopheles arabiensis ranges between 1.87 to $2.0 \%$ for $P$. falciparum in two Governates Haroob and Al-Khobah of the Jazan region, respectively.The wide spread of An. arabiensis in Jazan region with $>90 \%$ of the malaria cases caused by $P$. falciparum, along with infectivity rate ranges between 1.87 to $2.0 \%$ for $P$. falciparum in Al-Khobah and HaroobGovernates, suggests that $P$. falciparum is the most predominant malaria parasite and A. Arabiensis is a very efficient malaria vector in the region.Further detection for the sporozoite of Plasmodium species in Anopheles mosquitoes need to be conducted in the rest ofJazan region to determine their infectivity rates by malaria parasites. The importance of detailed knowledge of disease vectors along with their sporozoite rates is of vital importance in the promotion of area-specific control interventions and programs.

\section{CONFLICT OF INTEREST}

The authors declared no conflict of interest.

\section{REFERENCES}

Al-Eryani SM, Kelly-Hope L, Harbach RE, Briscoe AG, Barnish G, Azazy A 2016: Entomological aspects and the role of human behaviour in malaria transmission in a highland region of the Republic of Yemen. Malar J. 15:1.

Al-Maktari, M., and Bassiouny, H. 1999: Bionomics of Anopholine vectors in Zabid District, Al-Hodeidah, Governorate, Republic of Yemen, Eastern Mediterranean Health Journal. 5(4): 698-705.

Alsheikh, A.A. 2004:Studies on the ecology, vectorial role in malaria transmission and population structure of Anopheles arabiensis in the Tihama region of Saudi Arabia and Yemen. $\mathrm{PhD}$ thesis, University of Liverpool - Liverpool School of tropical medicine.

Al-Sheik, A. A. 2011 Larval habitat, ecology, seasonal abundance and vectorial role in malaria transmission of Anopheles arabiensis in Jazan Region of Saudi Arabia. Journal of the Egyptian Society of Parasitology. 41 (3): pp. 615-634.

Beier J., Asiago C., Onyango K., and Koros J.1988: ELISA absorbance cut-off method affected malaria sporozoite rate determination in wild Afrotropical Anopheles. Medical and Veterinary Entomology.2: 259-264.

Beier, J, and Koros, J. 1991: Visual assessment of sporozoite and blood meal ELISA samples in malaria field studies. J. Med. Entomol. (28): pp. 805-8.

Burkot T., Zavala F., Gwadz R., Collins F., Nurssenweig R., and Roberts D. 1984: Identification of malaria-infected mosquitoes by a two-site enzyme-linked immunosorbant assay. American Journal of Tropical Medicine and Hygiene. 33(2): 227-231.

Coetzee, M, and Le Sueur, D. 1988: Effects of salinity on the larvae of some Afro-tropical anopheline mosquitoes. Med. Vet. Entomol. 2, (4): pp. 385-90.

Cowman, A. F., \&Crabb, B. S. 2006: Invasion of red blood cells by malaria parasites. Cell. 124 (4): pp. 755-766.

Dash AP, Bendle MS, Das AK, Das M, Dwivedi SR. 1982: Role of Anopheles annularis as a vector of malaria in the inland of Orissa. J Com Dis. 14(3): 224.

Dye, C. 1986:Vectorial Capacity: Must we measure all its components? Parasitology Today. 2(8): 203-209.

El Hassan, I. M., Sahly, A., Alzahrani, M. H., Alhakeem, R. F., Alhelal, M.,Alhogail, A.andAtas, M. 2015: Progress toward malaria elimination in Jazan Province, Kingdom of Saudi Arabia: 2000-2014. Malaria journal. 14 (1): pp. 1-10.

Elmahdi Z.A, 1Nugud A.A., and Elhassan I.M. 2012: Estimation of malaria transmission intensity in Sennar state, central Sudan.EMRO Bulletin.18(9):951-6.

Gama, B. E., do ES Silva-Pires, F., Lopes, M. N. K. R., Cardoso, M. A. B., Britto, C., Torres, K. L., and de Fátima Ferreirada-Cruz, M.2007: Real-time PCR versus conventional PCR for malaria parasite detection in low-grade parasitemia. Experimental parasitology. 116 (4): pp. 427-432.

Garret- Jones, C., and Shidrawi G. 1969: Malaria vectorial capacity of a population of Anopheles gambiae: an exercise in epidemiological entomology. Bulletin of the World Health Organization. 40(4): $531-545$.

Ghosh KK, Chakarborty S, Bhattacharya S, Palit A, NeelamTandon, Hati AK. 1985: Anopheles annularis as a vector of malaria in rural West Bengal. Indian J Malariol. 22: 65-70.

Glick, JI. 1992: Illustrated key to the female Anopheles of South Western Asia \&t Egypt. Mosq. Syst. 24(2): 125-153.

Gunasekaran K, Sahu SS, Parida SK, Sadanandane C, Jambulingam P, Das PK. 1989:Anopheline fauna of Koraput district, Orissa State, with particular reference to transmission of malaria. Indian J Med Res. 89: 340-3.

Hamad AA, NugudAel H, Arnot DE et al. 2002: A marked seasonality of malaria transmission in two rural sites in eastern Sudan. ActaTropica. 83, 71-82.

Harada M, Ishikawa H, Matsuoka H, Ishii A. Suguri S. 2000: Estimation of the sporozoite rate of malaria vector using the polymerase chain reaction and a mathematical model. Acta Med Okayama. 54(4): 165-71.

Mahapatra, N., N.S. Marai, M.R. Ranjit, S.K. Parida, D.P. Hansdah, R.K. Hazract S.K. Kar. 2006: Detection of Plasmodium 
falciparum infection in Anopheles mosquitoes from Keonjhar district, Orissa, India. J Vect Borne Dis. 43, pp. 191-194.

Mattingly, PF \& Knight KL. 1956: The mosquito of Arabia, I. Bull. Brit. Meus. Nat. Hist.( Ent.). 4(3): 89- 141.

Moody, A. 2002:Rapid diagnostic tests for malaria parasites. Clin. Microbial.Rev. (15): pp.66-78.

Morassin, B., R. Fabre, A. Berry, and J. F. Magnaval. 2002: One year's experience with the polymerase chain reaction as a routine method for the diagnosis of imported malaria. Am. J. Trop. Med. Hyg.(66): pp. 503-508.

Oneeb M., Maqbool A., Lateef M., Babar M. E. 2015: Detection of Plasmodium falciparum infection in Anopheles stephensi in Punjab, Pakistan. Pakistan journal of zoology. 47(4):11921195.

Reisen,W., and Boreham,P. 1982: Estimates of malaria vectorial capacity for Anopheles culicifacious and Anopheles stephensi in rural Punjab province Pakistan. Journal of Medical Entomology. 19(1):98-103.

Scott JA, Brogdon WG, Collins FH. 1993: Identification of single specimens of the Anopheles gambiae complex by the polymerase chain reaction. Am J Trop Med Hyg.49: 520529.

Sebai, Z. 1988: Malaria in Saudi Arabia. Trop. Doctor. (18): pp. 183-88.

Shililu J, Ghebremeskel T, Seulu F et al. 2004: Seasonal abundance, vector behavior, and malaria parasite transmission in Eritrea. J Am Mosq Control Assoc. 20, 155-64.

Snounou, G. S., S. Viriyakosol, X. P. Zhu, W. Jarra, L. Pinheiro, V. E. do Rosario, S. Thaithong, and K. N. 1993a: Brown. High sensitivity of detection of human malaria parasites by the use of nested polymerase chain reaction. MolBiochemParasitol. 61(2):315-20

Snounou G, Pinheiro L, Goncalves A, Fonseca L, Dias F, Brown KN. 1993b: The importance of sensitive detection of malaria parasites in the human and insect hosts in epidemiological studies, as shown by the analysis of field sample from Guinea Bissau. Trans R Soc Trop Med Hyg. 87: 649-53.

Tassanakajon A, Boonsaeng V, Wilairat P, Panyim S. 1993: Polymerase chain reaction detection of Plasmodium falciparum in mosquitoes. Trans R Soc Trop Med Hyg. 87: 273-5.

Tirados I, Costantini C, Gibson G, Torr SJ 2006: Blood-feeding behaviour of the malarial mosquito Anopheles arabiensis: implications for vector control.Med Vet Entomol. 20(4):425-37.

Waters AP, McCutchan TF. 1989: Rapid, sensitive diagnosis of malaria based on ribosomal RNA. Lancet. 17; 1 (8651) 13431346.

WHO. 1992: Entomological field techniques for malaria control. Part I, Learners guide. Geneva, World Health Organization.

WHO. 2011: World malaria report 2011. Geneva, World Health Organization.

WHO. 2014: World malaria report 2013. Geneva: World Health Organization; http://www.who.int/malaria/publications/ world_malaria_report_2013/en/.

WHO. 2016: Malaria Fact sheet. 2016. Available from: http:// www.who.int/mediacentre/factsheets/fs094/en/ (Accessed: 25/04/2016).

Wilson MD, Ofosu-Okyere A, Okoli AU, McCall PJ, Snounou G. 1998: Direct comparison of microscopy and polymerase chain reaction for the detection of Plasmodium sporozoites in salivary glands of mosquitoes. Trans R Soc Trop Med Hyg. 92: 482-3.

Wirtz, R. A., T. R. Burkot, P. M. Graves, and R. G. Andre. 1987: Field evaluation of enzyme-linked immunosorbent assays for Plasmodium falciparum and Plasmodium vivax sporozoites in mosquitoes (Diptera: Culicidae) from Papua New Guinea. J. Med. Entomol. 24: 433-437.

Zahar, A. 1985: Vector Bionomics in Epidemiology and Control of Malaria Part I, WHO Geneva. 